\title{
Importance of TNF- $\alpha$ in the course of acute infection with Trypanosoma cruzi: influence of its inhibition by pentoxifylline treatment
}

\author{
Sonia G Andrade/ ${ }^{+}$, Lorena dos Anjos Magalhães, Daniel Huber Pessina \\ Laboratório de Chagas Experimental, Autoimunidade e Imunidade Celular, Centro de Pesquisas Gonçalo Moniz-Fiocruz, Rua Valdemar \\ Falcão 121, 40295-001 Salvador, Bahia, Brasil
}

\begin{abstract}
Infection of C3H/He mice with the Peruvian strain of Trypanosoma cruzi (Biodeme type I, Z2b), a macrophagotropic strain, determined severe parasitism of macrophages, necrosis of the spleen, and high host mortality. In the present study, pentoxifylline (PTX), an inhibitor of TNF- $\alpha$ was investigated on its action upon splenic necrosis, parasitemia and host survival. Immunohistochemical data suggested the importance of this cytokine in parasite destruction and decreasing of parasitemia, although paradoxically contributing to the high mortality of infected mice. Necrotic lesions involving several organs, specially the heart, in acute Chagas disease, are important aggravating factors, increasing cardiac morbidity. Advantage of inhibiting TNF- $\alpha$ action was herein investigated. Infected mice were divided into two groups: untreated $(n=24)$, and PTX treated mice $(n=25)$. PTX was administered in two daily doses of $30 \mathrm{mg} / \mathrm{kg} /$ $b w$, by intraperitoneal route. Normal controls either treated with PTX or saline were also included. Histopathology of the spleen and in situ immunolabeling of TNF- $\alpha$, using anti-TNF- $\alpha$ monoclonal antibody, were performed. Necrotic areas were evaluated by morphometry. Mice treated with PTX showed a significant decrease of necrotic areas and diminution of TNF- $\alpha$ expression in spleen tissue, suggesting that PTX treatment could control TNF- $\alpha$ effects, and thus be used as an adjuvant in the treatment of acute Chagas'disease.
\end{abstract}

Key words: Trypanosoma cruzi - necrosis - spleen - TNF- $\alpha$ - pentoxifylline

Necrosis of different cells and tissues is a prominent finding seen in acute Trypanosoma cruzi infection. It involves parasitized macrophages, cardiac and skeletal muscles cells in different animal species such as mice, dogs, and Callomys callosus (Andrade 1991, Cordeiro et al. 1997, Magalhães-Santos et al. 2004). In acute Chagas' disease in humans, necrosis of cardiac myocells, either containing intracellular forms of $T$. cruzi or in the absence of parasites, constitutes an outstanding feature in advanced acute chagasic myocarditis (Andrade 1991). In experimental studies (Cordeiro et al. 1997) it was demonstrated extensive focal necrosis of the spleen, involving macrophages and the intracellular parasites, related with high and early mortality of the animals and a rapid drop of parasitemia in mice infected with the $Y$ strain of T. cruzi. In a previous study we have investigated the in situ participation of TNF- $\alpha$ in cellular necrosis and destruction of parasitized macrophages in the spleen, during the infection with a macrophagotropic strain of T. cruzi (Lima et al. 2001). By immunohistochemical identification of that cytokine it was shown that TNF- $\alpha$ was expressed in focal necrotic areas within the germinal centers and red pulp of the spleen, indicating a pivotal importance of that cytokine in the exacerbation of tissue lesions. Activation of macrophages by intracellular parasites can stimulate their trypanocidal mechanism with production of TNF- $\alpha$ and toxic oxygen metabolites, especially nitric oxide (NO) (Gazzinelli et al. 1992, Silva

+ Corresponding author: sgandrade@cpqgm.fiocruz.br

Received 6 March 2007

Accepted 26 December 2007 et al. 1995). T. cruzi is a potent priming agent for TNF- $\alpha$ production by splenic cells in vitro (Tarleton et al. 1988). According to Dos-Reis (1997), cytokine production by stimulated macrophages, including TNF- $\alpha$, can be helpful for the control of parasitemia, but also induces toxic lesions, leading to death. According with Truyens et al. (1999) the parasitemic phase of T. cruzi infection in mice is associated with high levels of circulating TNF- $\alpha$. Besides playing a beneficial role early in infection, TNF- $\alpha$ also triggers harmful effects in the parasitemic phase, which are limited by the in vivo simultaneous endogenous production of soluble receptors (Truyens et al. 1999). Studying the role of IL-10, TGF- $\beta$, IFN- $\gamma$ and TNF- $\alpha$, regulating chemokine production and expression in IFN- $\gamma$ or TNF-R1-p55 deficient mice infected with T. cruzi, Aliberti et al. (2001) suggested an important role for IFN- $\gamma$ and TNF- $\alpha$ in the control of chemokine expression and production in experimental T. cruzi infection.

To further evaluate the role of TNF- $\alpha$ on the necrotic lesions and in the evolution of infection, revealed by the parasitemic levels and mortality in the experimental animal, we evaluated the effect of the inhibition of this cytokine by the use of pentoxifylline (PTX) an inhibitor of TNF- $\alpha$. PTX is a methylxantine derivative, with multiple properties and clinical use, as reviewed by Ward and Clissold (1987) and by Samlaska and Wimfield (1994). Some studies indicate that this drug suppresses TNF- $\alpha$ production by monocytes, and inhibits leucocyte stimulation by TNF- $\alpha$ and IL-1 (Sullivan et al. 1988, Bernard et al. 1995, Mandell 1995). Treatment with PTX has been also performed in patients with severe cerebral malaria (Wenisch et al. 1998), with the objective of to inhibit the action of TNF- $\alpha$, with improvement of the clinical picture in treated patients. 
In the present study, treatment with PTX has been assayed in mice infected with a macrophagotropic strain of T. cruzi, the Peruvian strain (Ps) (Andrade \& Magalhães 1997) to evaluate the influence of such treatment upon the course of infection, the parasitemia and mortality. The presence of necrosis of the spleen and the influence of PTX treatment in the expression of TNF- $\alpha$ in the spleen lesions were also evaluated by histopathological and immunohistochemical study.

The quantitative evaluation of TNF- $\alpha$ expression in necrotic lesions showed a significant decrease in treated animals, corresponding to decreased parasitemia. These findings could indicate an influence of this cytokine in the severity of acute infections with $T$. cruzi, and a possible control of the lesions by treatment with PTX.

\section{MATERIALS AND METHODS}

Experimental animal - $\mathrm{C} 3 \mathrm{H} / \mathrm{He}$ inbred mice, weighing 10 to $15 \mathrm{~g}$, raised in the animal facilities of the Centro de Pesquisas Gonçalo Moniz-Fiocruz, were used in the present study. Their maintenance complied with the guidelines for the human use of laboratory animals.

T. cruzi strain - The Ps of T. cruzi, a macrophagotropic strain (Andrade \& Magalhães 1997) (Biodeme type I, Z2b), was inoculated by intraperitoneal route. The inoculum represented $1 \times 10^{5}$ blood forms to $10 \mathrm{~g}$ of body weight.

Experimental groups - $64 \mathrm{C} 3 \mathrm{H} / \mathrm{He}$ mice, were divided into four groups: group A - 24 mice infected with the Ps; group B - 25 mice infected with this strain and treated with PTX; group C- 10 uninfected mice treated with PTX; group D- 5 intact controls.

Follow up of the experimental groups - Parasitemia was daily evaluated during the course of infection in five mice of each infected group and expressed as the means of parasites in peripheral blood counted in 50 microscopic fields (400X). Cumulative mortality was evaluated by daily counting of dead mice, excluding those previously sacrificed. The mortality rate was registered up to the 12th day post infection.

Treatment with PTX [1-(5-oxo-hexyl)-3, 7 dimethylxantine] - This drug was used in phosphate buffer solution (PBS), by intra-peritoneal injections. It was administered from the 3rd day of infection, in two daily doses of 30 $\mathrm{mg} / \mathrm{kg} / \mathrm{bw}$ every $12 \mathrm{~h}$. Treatment was performed until the last day of survival, i.e. the 13th day. Bioavailability of this drug: according with pharmaceutical indications (Sanofi Aventis Pharmaceutic Ltda), Trental ${ }^{\circledR}$ Vert is rapidly absorbed and its liberation is maintained for 10 to $12 \mathrm{~h}$ with constant levels during this period of time. Two daily doses every $12 \mathrm{~h}$ has been previously used by others (He \& Sharma 2005), intraperitoneally, without harmful effects.

Three mice from each experimental group were killed by exsanguination under halotane anesthesia in the 5th, 7th, 8th, 10th, 11th and 12th days after infection. Still alive, the animals were submitted to spleen perfusion, after section of the portal vein, by injection with cold PBS through the left ventricle of the heart. Complete necropsies were performed and fragments of the spleen, liver, heart and skeletal muscles were fixed into buffered for- malin (Milloning fixative), followed by paraffin embedding. Sections were stained with hematoxylin and eosin for histopathological study.

Fragments of the spleen were embedded in tissueteck (OCT compound-Miles Inc. Diagnostic Division, Elkhart, USA) frozen in liquid Nitrogen and cryopreserved in a freezer at $-70^{\circ} \mathrm{C}$. Sections of $6 \mu \mathrm{M}$ were cut in a cryostat at $-10^{\circ} \mathrm{C}$, fixed in dehydrated acetone and treated with PBS containing 0.1\% Saponin (Sigma St Louis, MO, USA) and $1 \%$ bovin serum albumin (BSA) (Sigma). For blocking non-specific binding, sections were treated with 39\% BSA in PBS for 20 min at room temperature. Sections were incubated overnight at $4^{\circ} \mathrm{C}$ in a humidified chamber with rat IgG anti-mouse -TNF- $\alpha$ antiserum (MPC-XT3) (Pharmigen, San Diego, CA, USA) diluted $1: 50$ in PBS pH 7.4/saponin 0.1\%/BSA 1\%. After washing with PBS and saponin, sections were incubated in normal sheep serum, for 20 min for additional blocking of non-specific binding. The slides were then incubated for $30 \mathrm{~min}$ at $37^{\circ} \mathrm{C}$ in a humidified chamber with sheep-antirat $\operatorname{IgG}$ antibody conjugated to peroxidase (BoehringerMannheim Biochemica, Germany) diluted 1:1000 in PBS. Inhibition of the endogenous peroxidase was achieved by a 30 min incubation in $0.3 \% \mathrm{H}_{2} \mathrm{O}_{2}$ at room temperature. The colour was developed with $0.06 \% 3,3^{\prime}$ - diaminobenzidine tetrahydrocloride (DAB) (Sigma) and $0.06 \% \mathrm{H}_{2} \mathrm{O}_{2}$ plus $1 \%$ dimethylsulfoxide (Sigma). Sections were counterstained with $1 \%$ methyl-green for $2 \mathrm{~min}$, dehydrated and mounted with Permount.

Positive control - Cells of the lineage J774 described as "macrophage like" (Ralph \& Nakoinz 1975, Van Furth et al. 1985) were maintained in RPMI cell culture medium with $10 \%$ bovine foetal serum and collected during the exponential phase growth. They were stimulated for $24 \mathrm{~h}$ with $10 \mathrm{mg} / \mathrm{ml}$ lipopolysacharide (LPS) from the cellular membrane of Escherichia coli (Sigma) in $\mathrm{CO}_{2}$ chamber, at $37^{\circ} \mathrm{C}$. Stimulated cells were centrifuged at $1.500 \mathrm{rpm}$ for $10 \mathrm{~min} 4^{\circ} \mathrm{C}$, washed with RPMI and centrifuged a second time at $1.500 \mathrm{rpm}$ for $10 \mathrm{~min}$. The pellet was suspended in PBS at a concentration of $10^{6}$ cells $/ \mathrm{ml}$, and re-centrifuged (Cytospin-3-Shandon, Life Sciences International, England) for adhesion to slides previously treated with Poly L-lisine.

Negative control - Normal rat serum from a diluted 1: 300 , was used in substitution of the primary antibody (rat IgG antimouse TNF- $\alpha$ ).

Morphometry - Quantitative evaluation of the necrotic areas in the germinal centers of the lymphoid follicles immunolabeled for TNF- $\alpha$ was performed in the mice both in untreated control and in the mice treated with PTX. For evaluation of the necrotic areas with positive labeling for TNF- $\alpha$ a total area of $213.0 \mathrm{~mm}^{2}$ was examined in each case (five fields of $42.6 \mathrm{~mm}^{2}$ ) being six mice from each group. For all semi-automated morphometry, an optical microscope (Zeiss) was used and the images were captured and evaluated using the program Axio Vision 3.1(1998-2002) (Carl Zeiss Vision GmbH, Germany).

Statistical analysis - Comparative non-parametric Mann-Whitney test was used with the significance level of $\mathrm{p}<0.05$. 


\section{RESULTS}

Parasitemia - As depicted in Fig. 1 evolution of parasitemia in the group A (infected untreated mice) showed the profile of the Biodeme type I, with an early parasitemic peak at the 8 th day post-infection. A difference was observed in the parasitemic evolution in the mice treated with PTX (B) showing a delayed increasing of the parasitemia with the higher peak by 12 days of infection.

Cumulative mortality - In the infected untreated group (A), $100 \%$ of the mice died until the 12 th day of infection; in the group B (treated with PTX), 100\% of mortality was attained in the 13 th day of infection (Fig. 2).

Histopathological study of the spleen - Group A: infection with $T$. cruzi determined a reactional state of the lymphoid follicles, with prominent germinal centers, with hyperplastic and vacuolated macrophages, containing amastigotes of T. cruzi. In untreated controls, necrosis of parasitized macrophages and of other cells of the spleen was present in the germinal centers, from the 7 th day of infection, being more intense in the 10th and 11th day post-infection (Figs 3A,C,E); group B: treatment with PTX determined a decrease of the size and intensity of necrotic lesions and of the reactive state of lymphoid follicles. A diminution of hyperplasia and parasitism of macrophages, as compared with infected, untreated control mice was also present (Figs 3B, D, F); group C: histology of the spleen and liver taken from uninfected mice treated with PTX disclosed no alterations; group D: intact controls, showed essentially normal splenic structure.

Immunohistochemistry - Evaluation of the presence of TNF- $\alpha$ in necrotic areas of the spleen- Positive control: J774 cells, treated with monoclonal anti-TNF- $\alpha$ antibody, represented the positive result (Fig. 4A); negative control: spleen sections of infected mouse, submitted to all steps for immunolabeling, excluding the primary antibody, presented negative reaction (Fig. 4B); group A- Infected untreated controls: staining with anti-TNF- $\alpha$ monoclonal antibody revealed positive staining of necrotic areas of the germinal centers, involving macrophages, disintegrated parasites and splenic tissue. TNF- $\alpha$ was present in a moderate degree from the 7th through the 9th day, but became more marked from the 10th to the 11th day post-infection (Figs 4C, E); group B- Infected mice treated with PTX: immunolabeling with anti-TNF- $\alpha$ monoclonal antibodies, revealed moderate positive reaction in the 7 th and 8 th day post-infection (corresponding to the period of four to five days following the beginning of treatment) (Fig. 4D); cases examined at the 9th and 11 th day post-infection (six to eight days after the beginning of treatment), presented negative results for TNF- $\alpha$ immunolabeling. Focal areas with disintegrated parasites were seen devoid of TNF- $\alpha$ labeling (Fig. 4F).

Morphometry - Results of evaluation of the necrotic areas immunolabeled for TNF- $\alpha$ : Quantitative evaluation of necrotic areas of the germinal centers of lymphoid follicles, with positive expression of TNF- $\alpha$, revealed significant differences $(p=0.04)$ between the groups $A$ and B. In the infected untreated group, most of the necrotic areas were positive for TNF- $\alpha$, considering the total area of $42.6 \mathrm{~mm}^{2}$ examined for each case. A significant predominance in the size of these areas in the control group (A) as compared with the treated with PTX (B), was detected (Fig. 5).

\section{DISCUSSION}

Results of the present investigation demonstrate an important influence of PTX in the control of macrophage activation and production of TNF- $\alpha$ in situ in the spleen of $\mathrm{C} 3 \mathrm{H} / \mathrm{He}$ inbred mice infected with the macrophagotropic Ps of T. cruzi. Due to the high virulence of the Ps (Biodeme type I) conjugated with the high susceptibility

\section{Parasitemia}

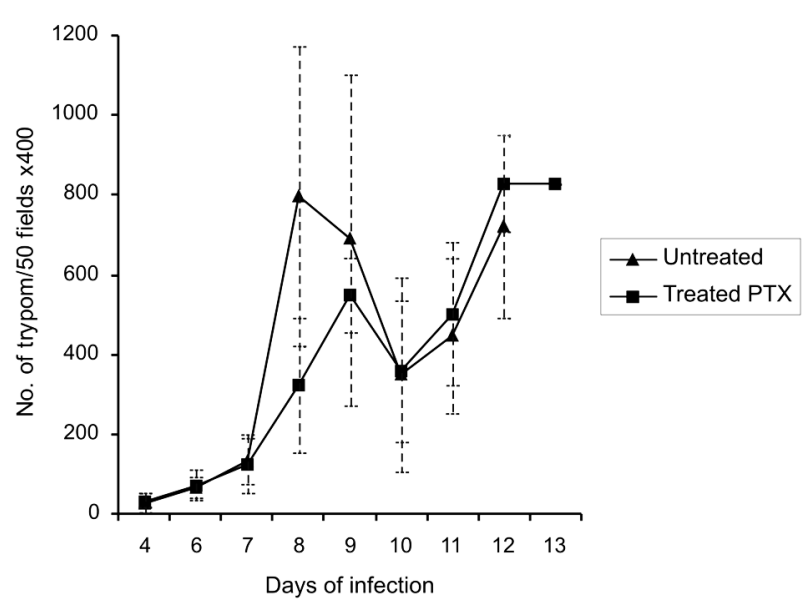

Fig. 1: parasitemia: means obtained by counting the trypomastigotes in the peripheral blood of five mice infected with the Peruvian strain of $T$. cruzi. In the group A (untreated controls), the profile of Biodeme type I strains is reproduced, with highest peak in the 8th day of infection; in group B, (treated with pentoxifylline) parasitemic evolution is delayed, with highest peak in the 12th day of infection.

\section{Cumulative Mortality}

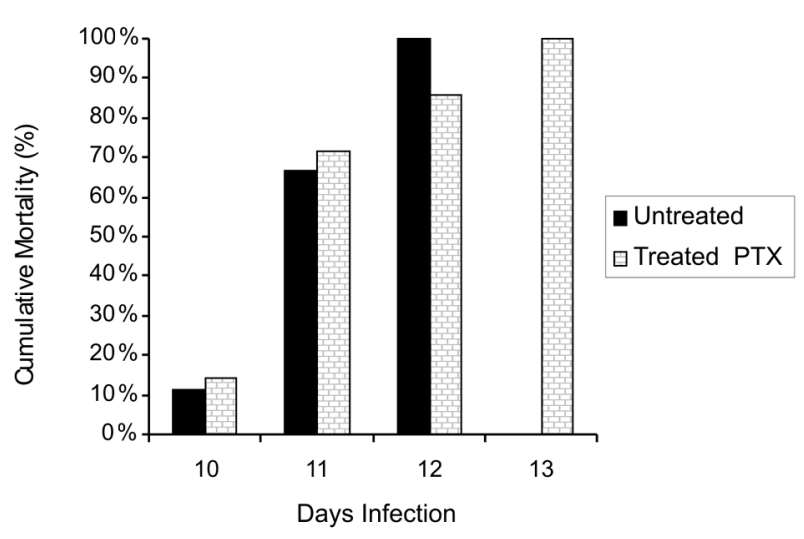

Fig. 2: cumulative mortality: the Peruvian strain of $T$. cruzi determined $100 \%$ of mortality at the 12 th day of infection for group A (untreated mice) and at the 13th day for the treated with pentoxifylline (group B). 

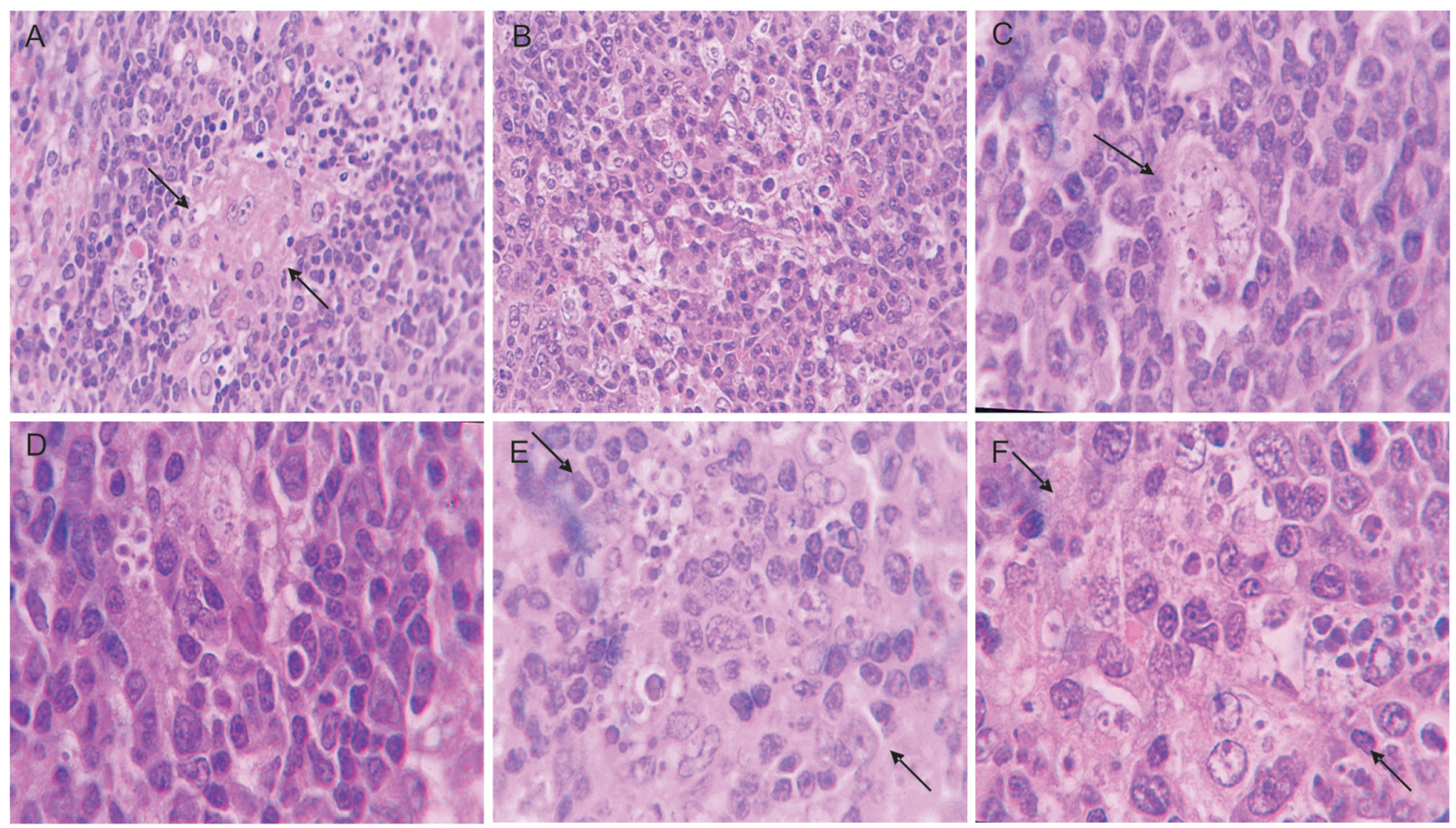

Fig. 3: histopathology: A, C, E: sections of the spleen of $\mathrm{C} 3 \mathrm{H} / \mathrm{He}$ mice infected with the Peruvian strain of T. cruzi. Untreated controls- A: 11th day of infection. Focal necrosis and cytoplasmic coalescence of macrophages (arrows). Presence of cells in apoptosis and vacuolized macrophage containing eosinophilic inclusion and parasite debris in the cytoplasm (400X); C: 7th day of infection. Intense vacuolization of macrophage (arrow) and presence of amastigotes of T. cruzi in disintegration, in the germinal center of lymphoid follicle (1000X); E: 7th day of infection. Necrosis and apoptosis of splenic cells; macrophages vacuolization with parasite debris (arrows) (1000X); B, D, F: sections of the spleen of $\mathrm{C} 3 \mathrm{H} / \mathrm{He}$ mice infected with the Peruvian strain of T. cruzi (1000X). Treated with pentoxiffyline- B: 7th day of infection. Moderated macrophages hyperplasia and vacuolization; cellular apoptosis, absence of necrosis and parasites (400X); D: 7th day of infection. Moderate hyperplasia and parasitism of germinal centers; presence of well preserved amastigotes in macrophage vacuole (1000X); F: 10th day of infection. Cellular hyperplasia of germinal center of lymphoid follicles and vacuolated macrophage containing apoptotic nuclei in the cytoplasm, in the absence of parasites (1000X).

of the mice lineage $(\mathrm{C} 3 \mathrm{H} / \mathrm{He})$, the course of infection was rapid and the parasitemia attained their maximum level in the lapse of four days, from the 8th to the 12th day. Differences occurring during this period were considered as significant. Even when we compare mouse lineages with different degrees of susceptibility this behaviour of biodeme type I strains is maintained (Andrade et al. 1985). However, in the present study, considering the mortality of treated mice, a delay of one day on the survival time could not be considered as biologically significant. The action of PTX was evidenced by a decrease in necrotic areas presenting TNF- $\alpha$, which was confirmed by computorized morphometry. Macrophage activation was diminished, as revealed by less hyperplasia and vacuolization when compared to controls. That was probably a result from a down regulation of microbicidal responses of macrophages, by PTX. According with Reed and DeGowin (1992), PTX has an influence in the natural killer (NK) cells activity probably inhibiting the production of IFN- $\gamma$ responsible for the activation of macrophages; a paradoxical effect was the diminished parasitism of macrophages. However experimental studies on leishmaniasis due to Leishmania amazonensis (Sá de Oliveira et al. 2000) demonstrate that treatment with PTX reduced macrophages vacuolization, with a more effective destruction of parasites by these cells. Infection with T. cruzi induces an innate response and stimulates NK $\mathrm{T}$ cells to produce IFN- $\gamma$ (Cardillo et al. 1996). That cytokine can stimulate macrophages to produce type 1 (proinflammatory) cytokines, such as IL-12, TNF- $\alpha$ and IFN- $\gamma$, and to liberate microbicidal agents such as $\mathrm{N}$ and O metabolites: $\mathrm{NO}$ and $\mathrm{H}_{2} \mathrm{O}_{2}$ (Gazzinelli et al. 1992, Silva et al. 1995, Dos-Reis 1997). This complex microbicidal reaction, could be helpful in controlling parasitemia, but on the other hand, may also provoke toxic lesions, leading to the death of the animals (Dos-Reis 1997). The $\mathrm{C} 3 \mathrm{H} / \mathrm{He}$ inbred mice are, characteristically, very susceptible to infection, both by myotropic and macrophagotropic strains of $T$. cruzi (Andrade et al. 1985). Investigations on the kinetics of macrophage activation by infection with $T$. cruzi, demonstrate that macrophages of susceptible mice produce higher levels of TNF- $\alpha$, than the macrophages of resistant mice, according to Russo et al. (1989) and Starobinas et al. (1991). These findings confirm the importance of the mouse genetic background in the relationship of immunological responses to infec- 

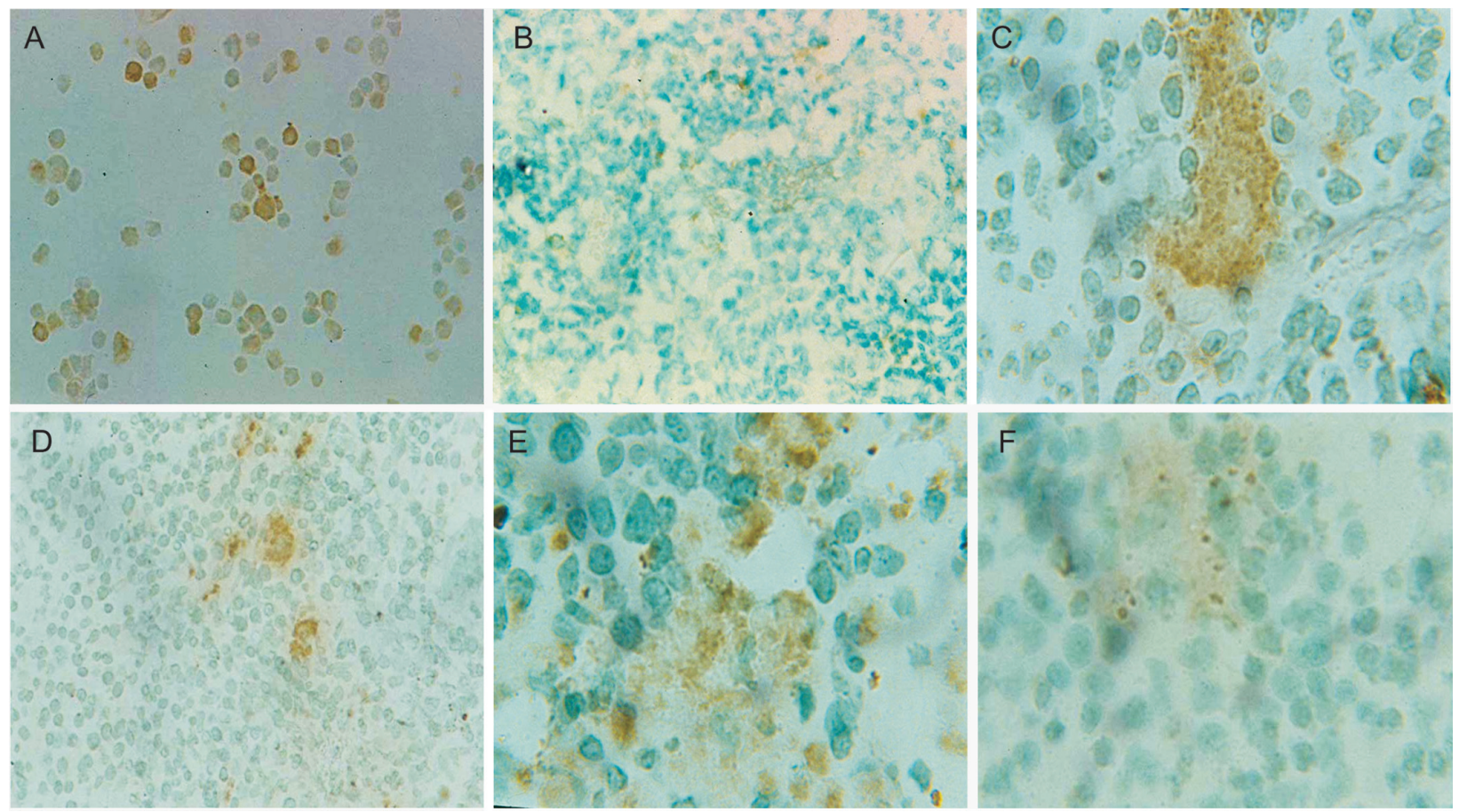

Fig. 4: immunohistochemical labeling of TNF- $\alpha$ in necrotic lesions of the spleen of $\mathrm{C} 3 \mathrm{H} / \mathrm{He}$ mice infected with T. cruzi. A: positive control: cells J774 stimulated with LPS; B: negative control: section of spleen of infected mouse, submitted to all steps for immunolabeling, excluding the primary antibody; C: section of spleen of a mouse in the 7th day of infection: untreated control, showing positive immunolabeling for TNF- $\alpha$ as intracellular deposits in macrophage containing disintegrated parasite, and grumous necrotic material (1000X); D: section of spleen of a mouse in the 7th day of infection, treated with pentoxifylline, presenting TNF- $\alpha$ expression in scattered areas in the spleen (400X); E: section of spleen of a mouse in the 10th day of infection: untreated control, showing area of necrosis of splenic cells and parasite debris with positive immunolabeling for TNF- $\alpha$ (1000X); F: section of spleen of a mouse in the10th day of infection, treated with pentoxifylline, presence of necrotic area with macrophages in disintegration and cells debris without TNF- $\alpha$ expression (1000X).

tion and the expression of TNF- $\alpha$. Previous study on the presence of TNF- $\alpha$ in the necrotic areas (Lima et al. 2001) have shown the predominance of these lesions in the $\mathrm{C} 3 \mathrm{H}$ (highly susceptible mice strain), in comparison with Swiss and DBA strains that are more resistant to T. cruzi infection.

Besides macrophages, other tissue cells, such as cardiac myocells, when infected with $T$. cruzi produce several regulatory cytokines, as shown by Teixeira et al. (2002) in mice. In C. callosus, a sylvatic reservoir of T. cruzi, Magalhães-Santos \& Andrade (2005) have demonstrated the participation of TNF- $\alpha$, IFN- $\gamma$ and TGF- $\beta$ in the necrotic lesions of the heart and skeletal muscles in experimental infection.

According to Mandell (1995), the anti-inflammatory effect of PTX inhibits the host tissue damage by activated macrophages, by reduction of inflammatory cytokines (especially TNF- $\alpha$ ) and by reversal of the effect of these cytokines on phagocytes. The effect of PTX on human monocytes has been investigated (Marques et al. 1999) and it has been shown that in pulmonary sarcoidosis, PTX inhibit, in vitro, the spontaneous TNF- $\alpha$ production by alveolar macrophages. Using another experimental model, Doherty et al. (1991) investigated the effect of PTX on endotoxin-stimulated TNF production in vitro and in vivo and showed that PTX inhibited TNF produc- tion by murine adherent peritoneal exsudated cells incubated with endotoxin; similarly it decreased the number of available TNF messengers RNA transcripts in peritoneal exsudates (Doherty et al. 1991).

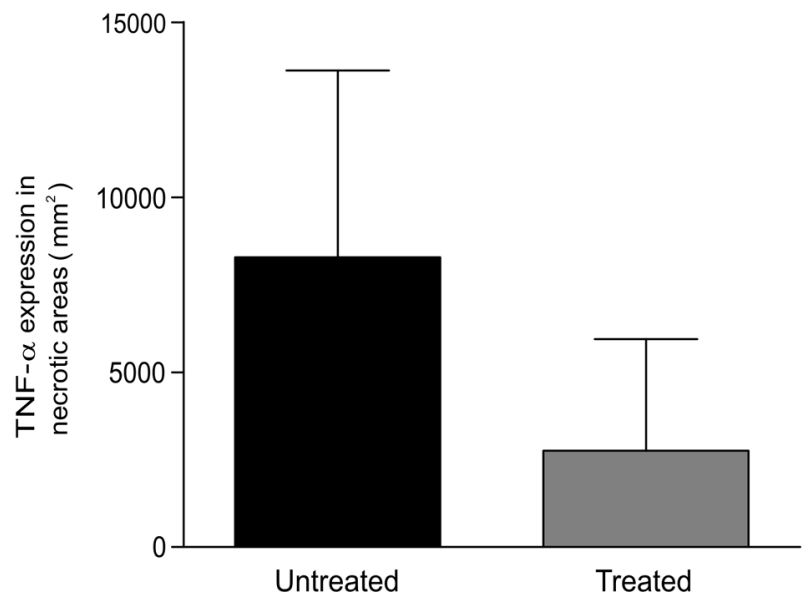

Fig. 5: morphometric evaluation of necrotic areas of the spleen with positive immunolabeling for TNF- $\alpha$. A significant predominance of TNF- $\alpha$ positivity was detected in the T. cruzi infected untreated controls $(\mathrm{p}<0.04)$. 
In human acute Chagas' disease, necrotic lesions of myocytes, especially the cells of the conduction tissue of the heart, represents an aggravating factor of the disease (Andrade \& Miziara 1983). Considering the severity of acute Chagas' disease in humans, with necrotic-inflammatory lesions of the heart, it seems important to investigate the anti-TNF- $\alpha$ action of PTX in experimental T. cruzi infection. The results could provide a coadjuvant to the treatment of acute Chagas' disease, with the objective of diminishing the harmful effects of TNF- $\alpha$ to cardiac cells.

\section{REFERENCES}

Aliberti JCS, Souto JT, Marino APMP, Lannes-Vieira J, Teixeira MM, Farber J, Gazzinelli RT, Silva JS 2001. Modulation of chemokine production and inflammatory responses in interferon- $\gamma$ and tumor necrosis factor-R1-deficient mice during Trypanosoma cruzi infection. Am J Pathol 158: 1433-1440.

Andrade SG, Magalhães JB 1997. Biodemes and zimodemes of Trypanosoma cruzi strains: correlations with clinical data and experimental pathology. Rev Soc Bras Med Trop 30: 27-35.

Andrade V, Barral-Netto M, Andrade SG 1985. Patterns of resistance of inbred mice to Trypanosoma cruzi are determined by parasite strain. Braz J Med Biol Res 18: 499-506.

Andrade ZA 1991. Pathogenesis of Chagas' disease. Res Immunol 142: 126-129.

Andrade ZA, Miziara HL 1983. Alterações do sistema de gênese e condução do estímulo cardíaco na fase aguda de doença de Chagas humana. Arq Bras Cardiol 40: 233-237.

Bernard C, Barnier P, Merval R, Esposito B, Tedgui A 1995. Pentoxifylline selectivity inhibits tumor necrosis factor synthesis in the arterial wall. J Cardiovasc Pharmacol 25 (Suppl. 2): 30-33.

Cardillo F, Voltarelli JC, Reed SG, Silva JS 1996. Regulation of Trypanosoma cruzi infection in mice by gamma interferon and interleukin 10: role of NK cells. Infect Immun 64: 128-134.

Cordeiro MZ, Dahia ACG, Andrade ZA 1997. Kinetics of Trypanosoma cruzi destruction in the mouse spleen. Rev Soc Bras Med Trop 30: 3-9.

Doherty GM, Jensen JC, Alexander HR, Buresh CM, Norton JA 1991. Pentoxifylline suppression of tumor necrosis factor gene transcription. Surgery 110: 192-198.

Dos-Reis G 1997. Cell-mediated immunity in experimental Trypanosoma cruzi infection. Parasitol Today 13: 335-342.

Gazzinelli RT, Oswald IP, Hilenys S, James SL, Sher A 1992. The microbicidal activity of IFNg treated macrophages against Trypanosoma cruzi involves an 1-arginine-dependent, nitrogen oxide-mediated mechanism inhibitable by IL-10 and TGF-b. Eur $J$ Immunol 22: 2501-2506.

He Q, Sharma RP 2005. Inhibition of tumor necrosis factor $\alpha$ signaling by anti-tumor necrosis factor $\alpha$ antibodies and pentoxifylline is unable to prevent fumonisin hepatotoxicity in mice. Toxicon 48: 404-413.

Lima ES, Andrade ZA, Andrade SG 2001. TNF- $\alpha$ is expressed at sites of parasite and tissue destruction in the spleen of mice acutely infected with Trypanosoma cruzi. Int J Exp Pathol 82: 327-336.

Magalhães-Santos I, Andrade SG 2005. Participation of cytokines in the necrotic-inflammatory lesions in the heart and skeletal muscles of Calomys callosus infected with Trypanosoma cruzi. Mem Inst Oswaldo Cruz 100: 555-561.
Magalhães-Santos I, Souza MM, Lima CSC, Andrade, SG 2004. Infection of Calomys callosus (Rodentia Cricetidae) with strains of different Trypanosoma cruzi biodemes: pathogenicity, histotropism, and fibrosis induction. Mem Inst Oswaldo Cruz 99: 407-413.

Mandell GL 1995. Cytokines, phagocytes, and pentoxifylline. J Cardiovasc Pharmacol 25 (Suppl.2): 20-22.

Marques LJ, Zeng L, Poulakis N, Guzman J, Costabel U 1999. Pentoxifylline inhibits TNF- $\alpha$ production from alveolar macrophages. Am J Respir Crit Care Med 159: 508-511.

Ralph I, Nakoinz R 1975. Phagocytosis and cytolysis by a macrophage tumour and its cloned cell line. Nature 257: 393-394.

Reed WR, De Gowin RL 1992. Supressive effect of pentoxifylline on natural killer cell activity. J Lab Clin Med 119: 763-771.

Russo M, Starobinas N, Ribeiro dos Santos R, Minoprio P, Eisen H, Hontebeyrie-Joskowicz M 1989. Susceptible mice present higher macrophage activation than resistant mice during infection with myotropic strains of Trypanosoma cruzi. Parasite Immunol 11: 385-395.

Sá de Oliveira T, Capp MN, Martins BJA, Rodrigues HA, Antonino RMP, Magalhães AV 2000. Action of pentoxifylline on experimental cutaneous leishmaniasis due to Leishmania (Leishmania) amazonensis. Mem Inst Oswaldo Cruz 95: 477-482.

Samlaska MCP, Winfield MC 1994. Pentoxifylline. J Am Acad Dermatol 30: 603-617.

Silva JS, Vespa GN, Cardoso MA, Aliberti JC, Cunha FQ 1995. Tumor necrosis factor alpha mediates resistance to Trypanosoma cruzi infection in mice by inducing nitric oxide production in infected gamma interferon-activated macrophages. Infect Immun 63: 4862-4867.

Starobinas N, Russo M, Minoprio P, Hontebeyrie-Joskowic M 1991. Is TNF- $\alpha$ involved in early susceptibility of Trypanosoma cruzi infected $\mathrm{C} 3 \mathrm{H} / \mathrm{He}$ mice? Res Immunol 142: 117-122.

Sullivan GW, Carper HT, Novick JR WJ, Mandell GL 1988. Inhibition of the inflammatory action of Interleukin-1 and tumor necrosis factor (alpha) on neutrophil function by pentoxifylline. Infect Immun 56: 1722-1729.

Tarleton RL 1988. Tumour necrosis factor (cachectin) production during experimental Chagas' disease. Clin Exp Immunol 73: 186-190.

Teixeira MM, Gazzinelli RT, Silva JS 2002. Chemokines inflammation and Trypanosoma cruzi infection. Trends Parasitol 18: 262-265.

Truyens C, Torrico F, Lucas R, Baetselier P, Buurman WA, Carlier Y 1999. The endogenous balance of soluble tumor necrosis factor receptors and tumor necrosis factor modulates cachexia and mortality in mice acutely infected with Trypanosoma cruzi. Infect Immun 67: 5579-5586.

Van Furth R, Van Shadewijk-Neuswstad M, Elzenga-Claasen I, Cornelisse C, Nibbring P 1985. Morphological, cytochemical, functional, and proliferative characteristics of four murine macropohage-like cell Lines. Cell Immunol 90: 339-357.

Ward A, Clissold SP 1987. Pentoxifylline - A review of its pharmacodynamics and pharmacokinetic properties and its therapeutic efficacy. Drugs 34: 50-97.

Wenisch C, Looareesuwan S, Wilairatana P, Parschalk B, Vannapann S, Wanaratana V, Werndorfer W, Graninger W 1998. Effect of Pentoxifylline on cytokine patterns in the therapy of complicated Plasmodium falciparum malaria. Am J Trop Med Hyg 58: 343-347. 